\title{
PENGEMBANGAN MODUL IPA BERBASIS KEARIFAN LOKAL KOPI PADA POKOK BAHASAN USAHA DAN ENERGI DI SMP
}

\author{
${ }^{1)}$ Aida Nurul Safitri, ${ }^{1}$ Subiki, ${ }^{1}$ Sri Wahyuni \\ 1) Program Studi Pendidikan Fisika FKIP Universitas Jember \\ E-mail: asafitri905@gmail.com
}

\begin{abstract}
Science module based on local wisdom of coffee was an alternative on develop learning tools by integrating local wisdom into science materials. This research was a development research using Plomp development model that was adjusted into 4 phases. The purposes of this research were to describe the validity of science module based on local wisdom of coffee, effectiveness and student's response. The effectiveness of science module was calculated from aspects of cognitive learning result and student learning acitivities. The data collection methods were validation, test, observation, questionnaire and documentation. Science module based on local wisdom of coffee on material work and energy in Junior High School was valid with final validation result 4.39. Field trials were conducted in class VIIIA Argopuro 2 Suci Junior High School with total of 39 students. The result of classical learning achievement was $82.05 \%$ and total percentage of student learning activity was $84.33 \%$ with very active category. Both values indicate that science modules based on local wisdom of coffee on material work and energy in Junior High School effective were viewed from aspects of learning result and student learning activities. Then student's response got very good response with percentage of response was $84.62 \%$.
\end{abstract}

Keywords: Science module, local wisdom, validity, effectiveness, student's response

\section{PENDAHULUAN}

Ilmu Pengetahuan Alam (IPA) merupakan konsep pembelajaran mengenai gejala alam yang mempunyai hubungan dengan kehidupan manusia dan objek kajian luas, yang terdiri dari kumpulan suatu konsep, prinsip, hukum, dan teori (Setyowati et al., 2013). Pembelajaran IPA yang menyajikan konsep nyata dalam kehidupan sehari-hari lebih berpotensi untuk mengembangkan pengalaman dan kompetensi siswa memahami alam sekitar berdasarkan konsep IPA (Listyawati, 2012). Oleh karena itu, suasana dan lingkungan belajar dalam proses pembelajaran IPA sangat mempengaruhi pencapaian kompetensi yang akan dicapai.

Suasana dan lingkungan belajar yang kondusif untuk proses pembelajaran IPA sangat beragam, tetapi dalam sudut pandang konteks, siswa akan lebih tepat jika mengoptimalkan kearifan lokal. Sesuai pendapat Kartono et al. (2010) bahwa proses pembelajaran IPA dapat dikembangkan dengan bertumpu pada keunikan dan keunggulan suatu daerah. Lingkungan fisik (alam) maupun lingkungan sosial budaya yang dimiliki oleh masyarakat Jember memiliki berbagai potensi yang dapat digali dan dikembangkan sebagai pendukung pembelajaran IPA. Kearifan lokal masyarakat Jember didefinisikan sebagai kemampuan (kompetensi) yang dimiliki oleh masyarakat Jember yang telah terbukti terlestarikan sampai saat ini. Salah satu contohnya ialah pengolahan kopi.

Pengintegrasian kearifan lokal ke dalam pembelajaran IPA sangat diperlukan karena banyak terdapat konsep-konsep IPA di dalamnya. Salah satu konsep IPA yang dapat ditemukan di lingkungan sekitar adalah materi usaha dan energi. Materi usaha dan energi dapat dipadukan dengan kearifan lokal kopi karena konsep usaha 
dan energi banyak dilakukan pada kegiatan pengolahan kopi.

Faktanya pengintegrasian kearifan lokal ke dalam proses pembelajaran khusunya IPA sangat jarang atau bahkan tidak pernah digabungkan. Prasetyo (2013) menyatakan bahwa nilai-nilai yang dianut oleh masyarakat lokal yang penuh dengan nilai-nilai kearifan lokal diabaikan dalam berbagai pembelajaran termasuk pembelajaran IPA. Hal ini diperkuat oleh hasil wawancara dengan siswa di salah satu SMP yang berada dekat dengan perkebunan kopi di daerah Panti Jember, yaitu SMP Argopuro 2 Suci yang menyatakan bahwa mereka tidak mengenal kearifan lokal daerah mereka dan dalam pembelajaran IPA tidak pernah mengaitkan tentang kearifan lokal. Hal tersebut tentu menimbulkan keprihatinan karena pengetahuan siswa terhadap kearifan lokal daerahnya sendiri tidak ditumbuhkan di dalam pembelajaran.

Berdasarkan wawancara dengan guru IPA di sekolah tersebut, diperoleh data bahwa penggunaan bahan ajar di sekolah tersebut belum optimal. Bahan ajar yang digunakan ialah buku teks dari berbagai penerbit. Buku yang diperoleh dari berbagai penerbit memiliki beberapa kekurangan, yaitu sajian pada buku tersebut masih bersifat umum dan belum disesuaikan dengan lingkungan belajar siswa seperti keunggulan daerah.

Masalah lain ialah karakteristik siswa di SMP Argopuro 2 Suci cenderung kurang aktif di dalam pembelajaran. Berdasarkan wawancara dengan guru dan observasi diperoleh data bahwa keberanian siswa untuk mengajukan pendapat dan bertanya kurang. Maulida et al. (2015) menyatakan bahwa aktivitas siswa yang rendah juga mengakibatkan kejenuhan siswa dan rendahnya semangat dalam belajar yang mengakibatkan rendahnya hasil belajar kognitif siswa. Tanpa adanya aktivitas siswa proses belajar mengajar tidak dapat berlangsung dengan baik.

Bahan ajar berupa modul berbasis kearifan lokal kopi dapat digunakan sebagai salah satu solusi untuk mengintegrasikan kearifan lokal ke dalam suatu pembelajaran IPA. Tujuan penggunaan modul IPA berbasis kearifan lokal tersebut agar siswa dapat terarahkan sesuai tujuan pembelajaran, sehingga kesadaran siswa untuk menjaga, melestarikan dan mengembangkan lingkungannya juga tumbuh seiring dengan materi IPA yang diterimanya. Hal tersebut sesuai dengan pendapat Martawijaya (2014) bahwa buku fisika peserta didik yang berbasis kearifan lokal menempati posisi strategis dalam pembelajaran untuk meningkatkan karakter dan ketuntasan belajar.

Penelitian yang relevan dengan kearifan lokal yaitu penelitian yang dilakukan oleh Warpala et al. (2010) diperoleh hasil bahwa bahan ajar pembelajaran sains berbasis kearifan lokal dapat meningkatkan pemahaman konsep dan kinerja ilmiah siswa. Tujuan penelitian ini antara lain: 1) untuk mendeskripsikan validitas modul IPA berbasis kearifan lokal kopi, 2) untuk mendeskripsikan efektivitas modul IPA berbasis kearifan lokal kopi ditinjau dari aspek hasil belajar dan aktivitas belajar siswa, dan 3) untuk mendeskripsikan respon siswa terhadap penggunaan modul IPA berbasis kearifan lokal kopi.

\section{METODE}

Jenis penelitian ini adalah penelitian pengembangan. Penelitian pengembangan digunakan untuk menghasilkan produk tertentu dan menguji keefektifan produk tersebut. Produk yang dimaksud berupa modul IPA berbasis kearifan lokal kopi pada pokok bahasan usaha dan energi di SMP. Penelitian ini menggunakan desain model pengembangan Plomp. Bentuk alur pengembangan model Plomp dapat dilihat pada Gambar 1. 


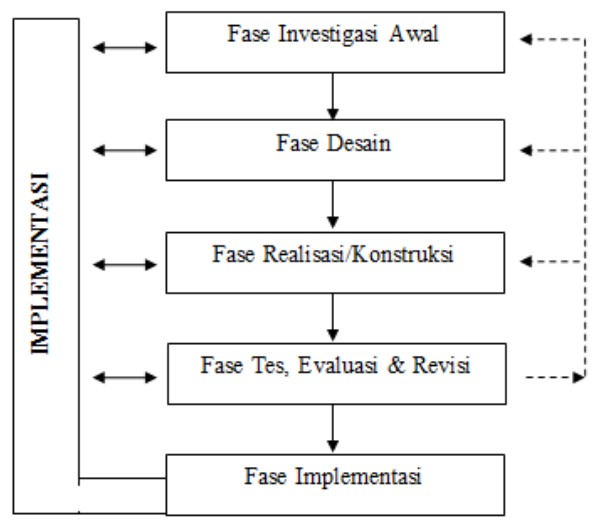

Gambar 1. Alur tahapan pengembangan model Plomp

Model Plomp yang digunakan dalam penelitian pengembangan ini dibatasi sampai pada fase tes, evaluasi dan revisi sehingga pada fase implementasi tidak dilaksanakan. Pembatasan ini dilakukan karena pada fase implementasi memerlukan proses yang panjang dan waktu yang lama.

Tahap terakhir yaitu, fase tes, evaluasi dan revisi yang terdapat dua kegiatan utama, yakni kegiatan validasi dan uji coba lapangan. Kegiatan validasi terdiri dari validasi ahli, yaitu 2 dosen Program Studi Pendidikan Fisika Universitas Jember dan validasi pengguna, yaitu 2 guru bidang studi IPA SMP Argopuro 2 Suci. Instrumen yang digunakan yaitu lembar validasi. Aspek yang dimunculkan antara lain aspek kelayakan isi, penyajian, kegrafikaan dan bahasa. Selanjutnya hasil validasi dianalisis menggunakan rumus:

Keterangan:

$$
V_{a}=\frac{\sum_{j=1}^{n} A_{i}}{n}
$$

$V_{a}$ : nilai rerata total untuk semua aspek

$A_{i}$ : rerata nilai untuk aspek ke-i

$n$ : banyaknya aspek

Kriteria menyatakan modul IPA berbasis kearifan lokal kopi yang dikembangkan memiliki derajat validitas yang baik, jika minimal tingkat validitas yang dicapai adalah tingkat valid, yaitu $4 \leq V_{a}<5$ (Hobri, 2010: 52-54).

Kegiatan uji coba lapangan dilakukan untuk mendapatkan data efektivitas modul IPA yang dikembangkan ditinjau dari aspek hasil belajar siswa dan aspek aktivitas belajar siswa serta untuk mengetahui respon siswa.

Instrumen perolehan data untuk efektivitas modul ditinjau dari aspek hasil belajar, yaitu menggunakan soal post test. Teknik analisis data dihitung melalui presentase ketuntasan hasil belajar klasikal siswa dengan rumus:

$$
K B=\frac{N^{\prime}}{N} \times 100 \%
$$

Keterangan:

$P$ : presentase ketuntasan belajar

$$
\text { klasikal }
$$

$n:$ jumlah siswa yang tuntas

$N$ : jumlah seluruh siswa

(Yensy, 2012)

Modul IPA berbasis kearifan lokal kopi yang dikembangkan dianggap efektif jika nilai hasil belajar siswa tuntas secara klasikal sebesar $\geq 80 \%$ (Hobri, 2010: 58).

Selanjutnya efektivitas ditinjau dari aspek aktivitas belajar siswa, yaitu diukur menggunakan instrumen lembar observasi. Aktivitas belajar siswa dihitung berdasarkan persentase aktivitas siswa dengan rumus:

$$
P_{a}=\frac{A}{N} \times 100 \%
$$

Keterangan :

$$
\begin{array}{ll}
P a & : \text { presentase aktivitas siswa } \\
A & : \begin{array}{l}
\text { jumlah skor tiap indikator } \\
\text { aktivitas yang diperoleh siswa }
\end{array} \\
N & : \begin{array}{l}
\text { jumlah skor maksimum tiap } \\
\text { indikator aktivitas siswa }
\end{array}
\end{array}
$$

Kriteria menyatakan modul yang dikembangkan dikatakan efektif, jika aktivitas siswa yang dicapai adalah aktif, yaitu $60 \%<\mathrm{Pa} \leq 80 \%$ (Basir dalam Wardiningrum, 2015: 44-52).

Terakhir yaitu untuk mengetahui respon. Instrumen perolehan data yang digunakan untuk respon siswa adalah lembar angket respon. Persentase respon siswa dihitung dengan menggunakan rumus:

Keterangan:

$$
P_{a}=\frac{A}{B} \times 100 \%
$$

$P_{a}:$ presentase respon 
A : total skor respon yang dicapai

B : total skor maksimal

(Trianto, 2009:241-242)

Kriteria menyatakan modul yang dikembangkan mendapatkan respon yang baik dan dapat dikatakan praktis, jika minimal presentase yang dicapai adalah $\geq$ 61\% (Riduwan, 2013).

\section{HASIL DAN PEMBAHASAN}

Data hasil fase investigasi awal diperoleh data bahwa bahan ajar yang digunakan di SMP Argopuro 2 Suci adalah buku paket BSE dan LKS dari penerbit komersil. Sajian buku-buku teks pelajaran tersebut cenderung tebal yang berisi teori umum dan belum menggabungkan nilainilai kearifan lokal atau contoh konstektual di lingkungan sekitar. Selain itu, diperoleh hasil analisis siswa yaitu siswa kelas VIII A lebih terampil dalam menulis dan mencatat tetapi cenderung pasif saat pembelajaran dan belum memahami bahwa kopi adalah kearifan lokal daerahnya.

Fase desain dilakukan untuk merancang modul IPA berbasis kearifan lokal kopi yang dikembangkan. Modul IPA yang dikembangkan termasuk ke dalam bahan ajar cetak dengan ukuran A4 (21 x 29,7) $\mathrm{cm}$. Desain modul dirancang dengan menggunakan Microsoft Office Publisher 2010. Pada tahap ini pula dilakukan penyusunan perangkat pembelajaran yang digunakan sebagai penunjang dalam penelitian, antara lain silabus, RPP, instrumen penilaian berupa soal post test dan instrumen aktivitas belajar siswa serta angket respon siswa.

Fase realisasi/konstruksi dihasilkan secara utuh modul IPA berbasis kearifan lokal kopi pada pokok bahasan usaha dan energi di SMP yang siap untuk direalisasikan pada tahap berikutnya. Hasil dari tahap ini disebut dengan prototipe I. Selanjutnya hasil ini yang akan divalidasi oleh para validator pada tahap tes, evaluasi dan revisi.

Tahap tes, evaluasi dan revisi dilakukan 2 kegiatan utama, yaitu validasi dan uji coba lapangan. Kegiatan validasi terdiri dari validasi ahli dan pengguna. Data kuantitatif validasi ahli dan pengguna digunakan untuk mendapatkan nilai validitas akhir modul IPA berbasis kearifan lokal kopi yang dikembangkan. Validitas akhir ini menunjukkan spesifikasi modul yang dikembangkan memiliki kriteria valid dan dapat digunakan atau tidak. Adapun rincian analisis validitas akhir modul IPA berbasis kearifan lokal kopi pada pokok bahasan usaha dan energi di SMP dapat dilihat pada Tabel 1. berikut.

Tabel 1. Hasil analisis validasi

\begin{tabular}{lccc}
\hline Aspek & $\begin{array}{c}\text { Validitas } \\
\text { Rata- } \\
\text { rata tiap } \\
\text { Aspek }\end{array}$ & $\begin{array}{c}\text { Validi- } \\
\text { tas } \\
\text { Akhir }\end{array}$ & $\begin{array}{c}\text { Kri- } \\
\text { teria }\end{array}$ \\
\cline { 1 - 2 } $\begin{array}{l}\text { Kelayakan } \\
\text { isi }\end{array}$ & 4,25 & & \\
\cline { 1 - 2 } $\begin{array}{l}\text { Kelayakan } \\
\text { Penyajian }\end{array}$ & 4,41 & & \\
\cline { 1 - 2 } $\begin{array}{l}\text { Kelayakan } \\
\text { kegrafikaan }\end{array}$ & 4,39 & & Valid \\
\cline { 1 - 2 } $\begin{array}{l}\text { Kelayakan } \\
\text { Bahasa }\end{array}$ & 4,5 & & \\
\hline
\end{tabular}

Berdasarkan hasil analisis validasi pada Tabel 1. diperoleh nilai validitas akhir modul sebesar 4,39 sehingga memenuhi kriteria valid. Hal ini sesuai dengan penelitian Yulicahyani et al. (2017) bahwa modul pembelajaran IPA fisika materi suhu dan pemuaian berbasis potensi lokal "Kerajinan Logam Sayangan" termasuk dalam kategori valid. Kriteria valid sebesar 4,39 didapatkan karena nilai yang diperoleh dalam setiap aspek (kelayakan isi, penyajian, kegrafikaan dan bahasa) memperoleh nilai di atas rata-rata skor minimal. Sesuai BSNP (2007) menyatakan bahwa kelayakan isi mempunyai rata-rata skor minimal 2,75; kelayakan penyajian, kegrafikaan dan bahasa mempunyai ratarata skor minimal 2,5 pada setiap aspek.

Pada aspek kelayakan isi mendapatkan skor terendah dikarenakan keluasan dan kedalaman materi yang terdapat pada modul masih sulit untuk dipahami serta gambar, diagram dan ilustrasi kurang sesuai dengan basis kearifan lokal kopi. Beberapa indikator tersebut kemudian direvisi sesuai dengan 
saran atau masukan dari validator. Pada aspek kelayakan penyajian medapat skor 4,41 dikarenakan penyajian contoh soal dalam modul kurang mengambil contohcontoh dalam kearifan lokal kopi sehingga perlu dibenahi kembali.

Aspek kelayakan kegrafikaan memperoleh skor 4,42 dikarenakan penampilan unsur (judul kegiatan belajar, subjudul kegiatan belajar dan angka halaman/folio) tata letak modul telah konsisten pada setiap bagian modul. Pada aspek kelayakan bahasa memperoleh skor yang paling besar, yaitu 4,5 dikarenakan bahasa yang digunakan pada modul sudah sesuai dengan perkembangan intelektual siswa

Selanjutnya mengenai hasil analisis efektivitas modul IPA berbasis kearifan lokal kopi pada pokok bahasan usaha dan energi di SMP. Hasil analisis efektivitas modul IPA berbasis kearifan lokal kopi didasarkan pada hasil belajar kognitif melalui post test dan aktivitas belajar siswa.
Data hasil post test ditunjukkan pada Tabel 2. Berikut.

Tabel 2. Hasil analisis post test siswa

\begin{tabular}{lc}
\hline \multicolumn{1}{c}{ Data } & Hasil \\
\hline Jumlah siswa & 39 \\
\hline Rata-rata & 73,79 \\
\hline Nilai tertinggi & 96 \\
\hline Nilai terendah & 14 \\
\hline Jumlah siswa tuntas & 32 \\
\hline Jumlah siswa tidak tuntas & 7 \\
\hline Ketuntasan klasikal & $82,05 \%$ \\
\hline
\end{tabular}

Berdasarkan data tersebut diperoleh ketuntasan klasikal sebesar $82,05 \%$. Sesuai pendapat Hobri (2010) modul yang dikembangkan dianggap efektif jika nilai hasil belajar siswa tuntas secara klasikal sebesar $\geq 80 \%$. Sehingga dapat dikatakan bahwa modul IPA berbasis kearifan lokal kopi pada pokok bahasan usaha dan energi di SMP efektif ditinjau dari hasil belajar siswa. Hal ini sesuai dengan pendapat Mannan et al. (2015) yang menyatakan bahwa pengintegrasian perangkat pembelajaran dengan kearifan lokal efektif dalam mempengaruhi aspek kognitif siswa.

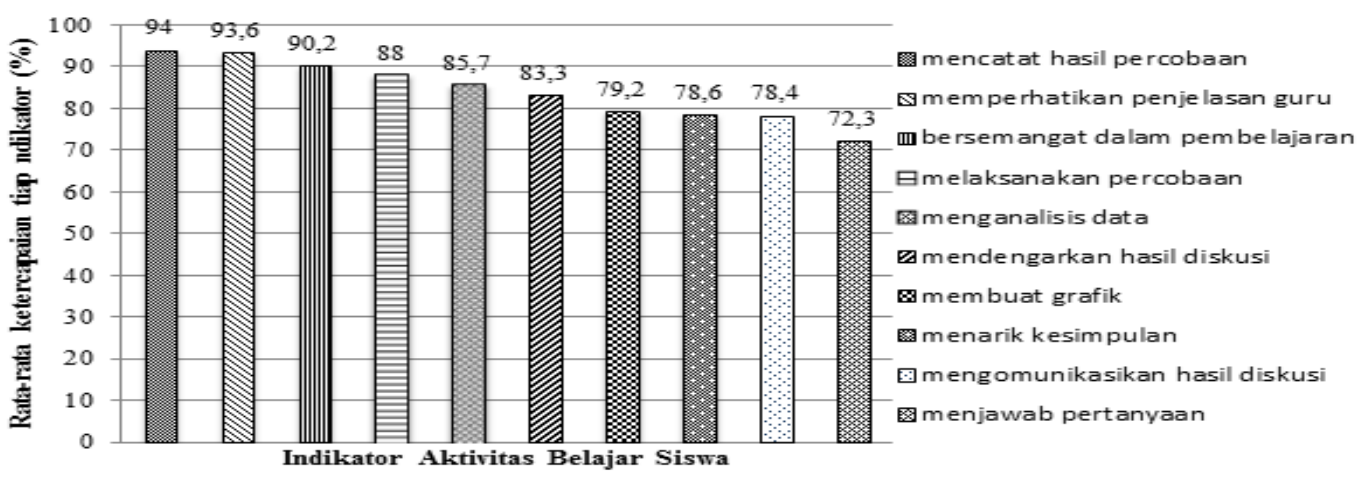

Gambar 2. Grafik presentase aktivitas belajar siswa

Efektivitas ditinjau dari aktivitas belajar siswa merupakan keefektifan modul yang dikembangkan dilihat dari aktivitas atau kegiatan yang dilakukan siswa selama pembelajaran menggunakan modul IPA berbasis kearifan lokal kopi yang dikembangkan. Observer melakukan observasi pada saat pembelajaran berlangsung dan menilai aktivitas belajar siswa yang nampak melalui instrumen aktivitas belajar siswa. Hasil analisis aktivitas belajar siswa selama pembelajaran berlangsung dapat dilihat pada Gambar 2 . Indikator writing activities (mencatat hasil percobaan) mempunyai presentase nilai yang tinggi sebesar $94 \%$ dikarenakan siswa kelas VIII A lebih terampil dalam hal menulis dan mencatat, sedangkan pada indikator oral activities (menjawab pertanyaan) mempunyai presentase nilai yang rendah yaitu sebesar 72,3\% dikarenakan siswa cenderung takut atau malu dalam menjawab pertanyaan yang 
diajukan guru. Hal ini didukung dengan penelitian Musfirotun (2010) yang menyatakan bahwa siswa masih malu-malu dan ragu-ragu dalam menjawab ataupun mempresentasikan hasil diskusi.

Presentase aktivitas belajar siswa keseluruhan diperoleh presentase nilai sebesar 84,33\% dengan kategori sangat aktif. Keaktifan siswa yang menunjukkan kategori sangat aktif dikarenakan rasa tertarik siswa untuk mempelajari modul IPA yang menggabungkan nilai-nilai kearifan lokal kopi pada materi usaha dan energi. Hal tersebut sependapat dengan Hasanah et al. (2015) yang menyatakan bahwa rasa tertarik siswa terhadap modul mitigasi bencana berbasis potensi lokal membuat siswa menjadi senang dan aktif dalam belajar.

Pembahasan selanjutnya mengenai respon siswa. Respon siswa dilakukan untuk mengetahui kepraktisan modul IPA yang dikembangkan. Adapun analisis data angket respon siswa terhadap penggunaan modul IPA berbasis kearifan lokal kopi dapat dilihat pada Tabel 3 berikut.

Tabel 3. Hasil analisis respon siswa

\begin{tabular}{lccc}
\hline \multirow{2}{*}{ Aspek } & $\begin{array}{c}\text { Indi- } \\
\text { kator }\end{array}$ & $\begin{array}{c}\text { Presen- } \\
\text { tase } \\
\text { Respon } \\
\left(\boldsymbol{P}_{\boldsymbol{a}}\right)\end{array}$ & Kriteria \\
\hline $\begin{array}{l}\text { Keter- } \\
\text { capaian } \\
\text { tujuan }\end{array}$ & 1 & $84,62 \%$ & Sangat baik \\
\cline { 2 - 4 } $\begin{array}{l}\text { Keter- } \\
\text { tarikan }\end{array}$ & 3 & $85,26 \%$ & Sangat baik \\
\cline { 2 - 4 } & 6 & $88,46 \%$ & Sangat baik \\
\cline { 2 - 4 } Materi & 4 & $85,26 \%$ & Sangat baik \\
\cline { 2 - 4 } & 7 & $86,92 \%$ & Sangat baik \\
\hline $\begin{array}{l}\text { Rata-rata } \\
\text { presentase } \\
\text { respon }\end{array}$ & & $85,54 \%$ & Sangat baik \\
\hline
\end{tabular}

Berdasarkan Tabel 3. pada aspek materi indikator 4 mendapatkan respon terendah yang berisi pernyataan "saya merasa kesulitan dalam mempelajari materi yang dikaitkan dengan kearifan lokal" dengan presentase sebesar 76,92\%. Hal ini wajar apabila siswa merasa sedikit kesulitan dalam mempelajari materi yang dikaitkan dengan kearifan lokal, sebab siswa belum terbiasa menerima materi yang dikaitkan dengan kearifan lokal. Suastra (2005) menyatakan bahwa pembelajaran berorientasi kearifan lokal lebih memberikan kesan yang kontekstual dalam pembelajaran sehingga siswa mudah memahami materi yang dipelajari.

Presentase respon tertinggi dicapai pada aspek ketercapaian tujuan indikator 3 yang berisi pernyataan "saya baru mengerti bahwa pembelajaran IPA dapat dikaitkan dengan kearifan lokal", yaitu sebesar $88,46 \%$. Hal ini dikarenakan siswa belum diperkenalkan apa itu kearifan lokal, sehingga melalui modul IPA yang dikembangkan ini siswa baru memahami apa itu kearifan lokal dan ternyata dapat dikaitkan dalam pendidikan khususnya pembelajaran IPA. Sesuai pendapat Wahyuni (2015) bahwa kearifan lokal seharusnya dipelihara dan dapat diimplementasikan dalam pendidikan.

Rata-rata presentase respon yang dicapai sebesar 84,62\% dengan kriteria sangat baik. Hal ini menandakan bahwa modul IPA berbasis kearifan lokal kopi yang dikembangkan dapat diterima dengan baik oleh siswa. Sesuai pendapat Hariri et al. (2016) bahwa siswa memberi respon positif terhadap pembelajaran berbasis sains budaya lokal ngaseup. Diperkuat pula oleh Sholakhuddin et al. (2016) bahwa respon siswa terhadap penggunaan PSB dengan AFKF berbasis kearifan lokal adalah sangat tinggi.

\section{SIMPULAN DAN SARAN}

Kesimpulan penelitian ini menunjukkan bahwa modul IPA berbasis kearifan lokal kopi yang dikembangkan: 1) valid dengan hasil validasi akhir sebesar $4,39 ; 2)$ efektif baik ditinjau dari aspek hasil belajar maupun aktivitas belajar siswa; dan 3) mendapatkan respon sangat baik dengan presentase respon sebesar 84,62\%.

Terdapat saran dalam penelitian ini, yaitu guru dapat lebih tegas dalam menyampaikan materi di depan kelas agar semua siswa dapat tuntas secara klasikal 
dan mengontrol siswa-siswa yang tidak aktif di dalam pembelajaran.

\section{DAFTAR PUSTAKA}

BSNP. 2007. Buletin BSNP. 2(1). Jakarta: BSNP.

Hariri, A. I., Kartimi, dan A. Mulyani. 2016. Penerapan Pembelajaran Berbasis Sains Budaya Lokal Ngaseup pada Konsep Sistem Reproduksi Manusia untuk Meningkatkan Keterampilan Berpikir Kritis Siswa Kelas XI SMAN 1 Maja. Scientiae Educatica: Jurnal Sains dan Pendidikan Sains. 5(1):1-14.

Hasanah, I., S. Wahyuni, dan R. W. Bachtiar. 2016. Pengembangan Modul Mitigasi Bencana Berbasis Potensi Lokal yang Terintegrasi dalam Pelajaran IPA di SMP. Jurnal Pembelajaran Fisika. 5(3): 226-234.

Hobri. 2010. Metodologi Penelitian Pengembangan: Aplikasi pada Penelitian Pendidikan Matematika. Jember: Pena Salsabila.

Kartono, Hairida, dan G. Bujang. 2011. Penelusuran Budaya dan Teknologi Lokal dalam Rangka Rekonstruksi dan Pengembangan Sains di Sekolah. Jurnal Cakrawala Kependidikan. 9(1): 19-26.

Listyawati, M. 2012. Pengembangan Perangkat Pembelajaran IPA Terpadu di SMP. Jurnal Pendidikan IPA.1(1):61-69.

Mannan, M. N., A. Sopyan, dan Sunarno. 2015. Pengembangan Perangkat Pembelajaran Berbasis Kearifan Lokal untuk Mengembangkan Karakter Positif Siswa SD. Jurnal Inovasi dan Pembelajaran Fisika. 2(2):141-146.
Martawijaya, M. A. 2014. Buku Fisika Peserta Didik Berbasis Kearifan Lokal untuk Meningkatkan Karakter dan Ketuntasan Belajar. Jurnal Sains dan Pendidikan Fisika. 10(3): 285292.

Maulida, R., Sahyar, dan N. Bukit. 2015. Pengembangan Bahan Ajar Fisika SMA Berbasis Investigasi pada Materi Fluida Dinamis untuk Meningkatkan Hasil Belajar Siswa. Jurnal Tabularasa PPS UNIMED. 12(3):285-293.

Musfirotun. 2010. Peningkatan Keaktifan Siswa dalam Pembelajaran IPA Melalui Pendekatan Cooperative Tipe Numbered Head Together pada Siswa Kelas V SD Negeri 2 Buwaran Mayong Jepara. Jurnal Kependidikan Dasar. 1(1): 39-47.

Prasetyo, Z. K. 2013. Pembelajaran Sains Berbasis Kearifan Lokal. PROSIDING : Seminar Nasional Fisika dan Pendidikan Fisika.

Riduwan. 2013. Skala Pengukuran Variabel-Variabel Penelitian. Bandung: Alfabeta.

Setyowati, R., Parmin, dan A. Widiyatmoko. 2013. Modul IPA Berkarakter Peduli Lingkungan Tema Polusi sebagai Bahan Ajar Siswa SMK N 11 Semarang. Unnes Science Education Journal. 2(2): 245-253.

Sholakhuddin, M. N., Sutarto, dan Subiki 2016. Paket Sumber Belajar (PSB) dengan Analisis Foto Kejadian Fisika (AFKF) Berbasis Kearifan Lokal pada Pembelajaran Fisika di SMK (Kajian Pengembangan pada Pokok Bahasan Fluida untuk SMK Jurusan Perikanan Kelautan). Jurnal Pembelajaran Fisika. 5(3): 253-260. 
Suastra, I. W. 2005. Merekonstruksi Sains Asli (Indigenous Science) dalam Upaya Mengembangkan Pendidikan Sains Berbasis Budaya Lokal di Sekolah. Jurnal Pendidikan dan Pengajaran IKIP Negeri Singaraja. 38(3): 377-396.

Trianto. 2009. Mendesain Model Pembelajaran Inovatif-Progresif. Jakarta: Cerdas Kencana Prenada Media.

Wahyuni, S. 2015. Developing Science Learning Instruments Based on Local Wisdom to Improve Students' Critical Thinking Skills. Jurnal Pendidikan Fisika Indonesia. 11(1): 1-7.

Wardiningrum, M. 2015. Penerapan Pembelajaran Cooperative Learning Model STAD Berbantukan Media Video Pembelajaran untuk Meningkatkan Aktivitas dan Hasil Belajar IPA. Jurnal Pena Sains. 2(1): 44-52.
Warpala, I. W. S., I. W. Subagia, dan I. W. Suastra. 2010. Pengembangan Bahan Ajar Berbasis Kearifan Lokal untuk Mata Pelajaran Sains SMP. Jurnal Penelitian dan Pengembangan Pendidikian. 4(3): 300-314.

Yensy, N. A. 2012. Penerapan Model Pembelajaran Kooperatif Tipe Examples Non Examples dengan Menggunakan Alat Peraga untuk Meningkatkan Hasil Belajar Siswa di Kelas VIII SMP N 1 Argamakmur. Jurnal Exacta. 10(1): 24-35.

Yulicahyani, T., T. Prihandono, dan A. D. Lesmono. 2017. Pengembangan Modul IPA Fisika Materi Suhu dan Pemuaian Berbasis Potensi Lokal "Kerajinan Logam Sayangan" untuk Siswa SMP di Kalibaru Banyuwangi. Jurnal Pembelajaran Fisika. 6(2): 116-123. 